
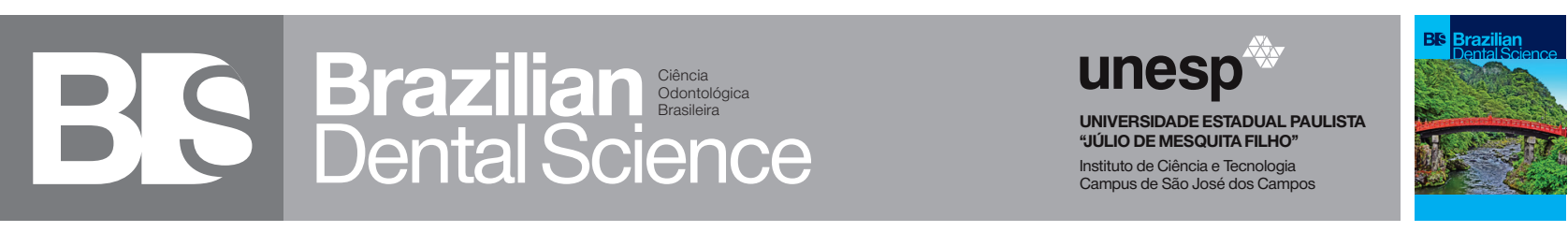

\title{
Lingual mandibular bone defect: imaging features in panoramic radiograph, multislice computed tomography and magnetic resonance imaging
}

Defeito ósseo submandibular: características de imagem em radiografia panorâmica, tomografia computadorizada multislice e ressonância magnética

Miki HISATOMI ${ }^{1}$, Luciana MUNHOZ ${ }^{2}$, Junichi ASAUMI ${ }^{1}$, Emiko Saito ARITA ${ }^{2}$

1 - Department of Oral and Maxillofacial Radiology - Okayama University - Okayama - Japan.

2 - Department of Stomatology - School of Dentistry - São Paulo University - São Paulo - SP - Brazil.

\section{ABSTRACT}

Stafne bone defect or mandibular bone depression is defined as a bone developmental defect usually filled with soft or salivary gland tissue. Lingual posterior variant incidence is less than $0.5 \%$. We reported a case of an 80 years old Asian female asymptomatic patient who underwent routine panoramic radiographic examination and a radiolucent area in mandible was noticed as an incidental finding, with initial provisional diagnosis of traumatic bone cyst, aneurysmal bone cyst and lingual mandibular bone defect. The patient was then referred to multislice computed tomography and magnetic resonance imaging. Computed tomography showed a hypodense area with discontinuity in mandible base. Magnetic resonance imaging demonstrated a hyperintense image eroding mandibular body in contact with submandibular gland, which corresponded to fatty tissue and due to these imaging findings, the final diagnosis was lingual mandibular bone defect. Although the defect is a benign lesion and interventional treatment is not necessary, radiolucencies in mandible should be detailed investigated, due to their radiographic features that can resemble to other intrabony lesions. Imaging examinations can provide great defect details, especially magnetic resonance imaging, which can allow the identification of glandular tissue continuity to the mandibular defect.

\section{KEYWORDS}

Bone cysts; Salivary glands; Magnetic resonance imaging; Computed tomography; Panoramic radiography.

\section{RESUMO}

O defeito ósseo do Stafne ou o defeito ósseo da mandíbula é definido como uma cavidade óssea geralmente preenchida com tecido glandular salivar. A incidência de variante lingual posterior é inferior a 0,5\%. Neste relato, foi descrito um caso de paciente de paciente de 80 anos, etnia asiática e assintomática que foi submetida a exames radiográficos panorâmicos de rotina no qual observou-se incidentalmente uma área radiolúcida na mandíbula. Os diagnósticos iniciais foram de: cisto ósseo traumático, cisto ósseo aneurismático e defeito ósseo mandibular. A paciente foi encaminhada para realização de tomografia computadorizada multislice e ressonância magnética. A tomografia computadorizada mostrou uma área hipodensa com descontinuidade na base da mandíbula. A ressonância magnética demonstrou uma imagem hiperintensa no corpo da mandíbula, em contato com a glândula submandibular, correspondendo a tecido adiposo. Devido a estes achados imaginológicos, o diagnóstico final foi de defeito ósseo mandibular. Embora este defeito seja uma lesão benigna sem necessidade de tratamento intervencionista, as radiolucências na mandíbula, por conta de sua semelhança com outras lesões intraósseas, devem ser devidamente investigadas. Os exames de imagem podem fornecer detalhes do defeito, especialmente imagens de ressonância magnética, que podem permitir a identificação da continuidade do tecido glandular ao defeito mandibular.

\section{PALAVRAS-CHAVE}

Cistos ósseos; Glândulas salivares; Imagem por ressonância magnética; Tomografia computadorizada; Radiografia panorâmica. 


\section{INTRODUCTION}

S tafne bone cavity or mandibular bone depression (MBD) is defined as a bone developmental defect which is filled with soft tissue, usually salivary gland [1,2] or fat tissue. MBD may present four different variants: lingual posterior [3], lingual anterior, lingual ramus and buccal ramus $[4,5]$. Lingual posterior variant incidence is between $0.10 \%$ and $0.48 \%$ [6] and represents the most frequently observed variant, with unique imaging features, particularly due to its classical location: bellow to the mandibular canal in mandible body.

MBDs were first reported in literature by Edward Stafne in 1942 [7] and since then, many hypotheses about MBD etiology have been postulated [6]. The most accepted hypothesis suggests that pressure from glandular tissue may lead to the bone erosion; precisely in the case of lingual mandibular bone depression (LMBD), pressure is from submandibular gland tissue $[1,8,9]$. However, it was also advocated that MBDs bone erosion is a result of acquired vascular lesion [10] or due to incomplete Meckel cartilage calcification during mandible ossification $[10,11]$.

Distinct depression contents were previously described in MBD cavities: the most usually reported is salivary gland tissue $[1,8]$, but connective tissue, muscles, blood vessels, fat and lymphoid tissue have been likewise noticed $[10,12]$. However, the diversity of tissues other than salivary gland tissue could be explained by accidental tissue displacement during surgical manipulation [6].

MBDs are typically asymptomatic $[4,13,14]$, rarely palpated [15] and are incidental findings in routine radiographic examinations $[4,9,10]$. Male patients are more often affected than female patients [16,17], mainly before 5 th to 6 th decades of life $[9,11]$. Manifold denominations have been adopted to describe MBDs, such as latent/idiopathic/ developmental bone cavity or cortical mandibular depression [4].

The defect does not require any treatment [2] since it is not considered a pathological lesion, but a structural variation in mandible [4] Nevertheless, regular follow-ups are strongly recommended $[4,18]$ and biopsy should be performed only when clinical symptoms are present or in atypical cases when the diagnosis is unreliable [2]. The main concern when a MBD is detected is to distinguish the depression from other lesions which need interventional treatment.

In the present case report, it is described a LMBD in an asymptomatic patient, emphasizing imaging features in panoramic radiographs, multislice computed tomography (MCT) and magnetic resonance imaging (MRI).

\section{CASE REPORT}

\section{Case history and clinical findings}

A female Asian patient (80 years old) was referred to the Okayama University Hospital for further evaluation of a radiolucent area in left posterior mandible. The lesion was an incidental finding on a panoramic radiograph. Patient had no clinical complaints and her medical history was unremarkable.

Patient extra-oral examination demonstrated absence of facial asymmetry nor any palpated bulging. Intra oral examination did not evince any abnormal finding.

\section{Imaging evaluations}

The panoramic radiograph revealed a round-shaped radiolucency in left mandible body, near to mandible angle and in the third molar area, bellow mandibular canal, with well-defined borders and an unilocular internal appearance. The lesion was homogeneously radiolucent, had thin discontinuous sclerotic margins, continuity with mandible base and measured a 1,21 centimeter in its largest diameter. The mandibular base cortical was thinner. No alterations were observed in the surrounding tissues, such as periosteal reaction or anatomical structures displacement (for instance, the mandibular canal), as demonstrated in Figure 1. 


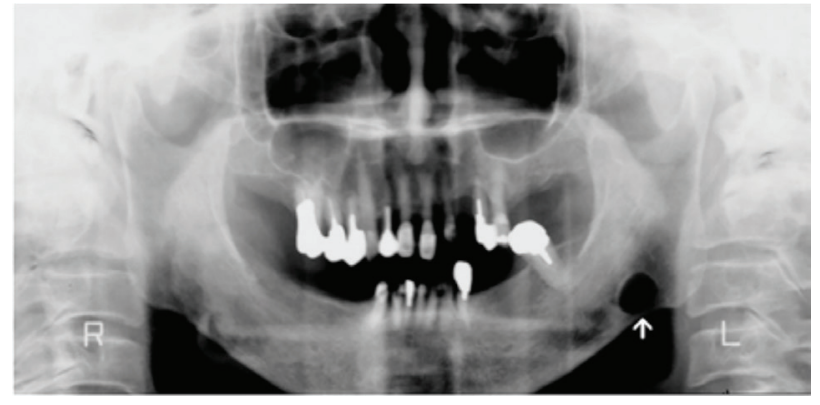

Figure 1 - Panoramic radiography of the case. Note the roundshape radiolucent area in the mandibular body, left side, with a thin discontinuous sclerotic border and continuity with mandible border.

For the radiolucent area detected in panoramic radiograph, a provisional diagnosis hypothesis was stated. At this point, traumatic or aneurysmal bone cyst, odontogenic keratocyst and LMBD were considered. The patient was then referred to MCT and, at last, magnetic MRI to detailed investigation.

Non-contrast-enhanced, high resolution MCT with 16 slices (Toshiba Activion, Medical Systems Corporation, Japan) was used for MCT imaging. Acquisition imaging parameters were: $0,5 \mathrm{~mm}$ slice thickness; $1,0 \mathrm{~mm}$ Spacing Between Slices; $250 \mathrm{~mm}$ field of view; $120 \mathrm{kV}$ peak and 250mA. MCT sagittal slices revealed a circle-shaped hypodense area, continuous to the mandible base, with a well-demarcated hyperdense sclerotic margin (figure $2 \mathrm{~A}$ ). Evident discontinuity in mandible base cortical was also noticed in sagittal slices, as demonstrated in figure $2 \mathrm{~B}$.

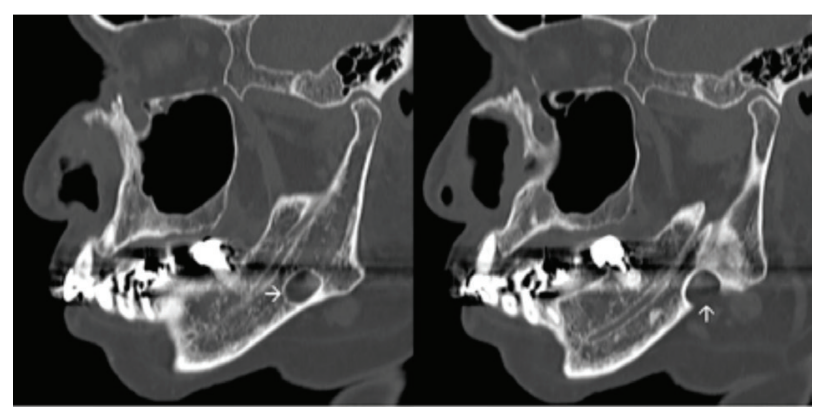

Figure 2 - Multislice computed tomography sagittal images. Figure 2A shows the circle-shape hypodense area, will-defined, near to mandible angle, with a visible sclerotic border. Figure 2B shows a hypodense area in another slice, with interruption of mandible cortical bone at the mandibular base surface.
Furthermore, MCT coronal slice (figure 3 ) as well as axial slice (figure 4) demonstrate a lingual bone put in the defect area. Discontinuity of the lingual bone is also observed. The hypodense area did not affect the mandibular canal nor any periosteal reaction was evinced.

MRI was performed in a 3 Tesla MRI system (Siemens Magnetom Skyra, Siemens Munich, Germany) using dedicated head and neck surface coils. Axial T1 and T2 weighted images were obtained. The section thickness was $4 \mathrm{~mm}$.

From MRI, T1-weighted images evinced the soft tissue content in mandible body area. In axial slice (figure 5), hyperintense signal was evinced in mandible body, with similar sign to a surrounding fat tissue area (figure 5, demarcated area 3 ). As in figure 5, figure 6 , frontal slice, demonstrates mandible hypointense cortical markedly interrupted.

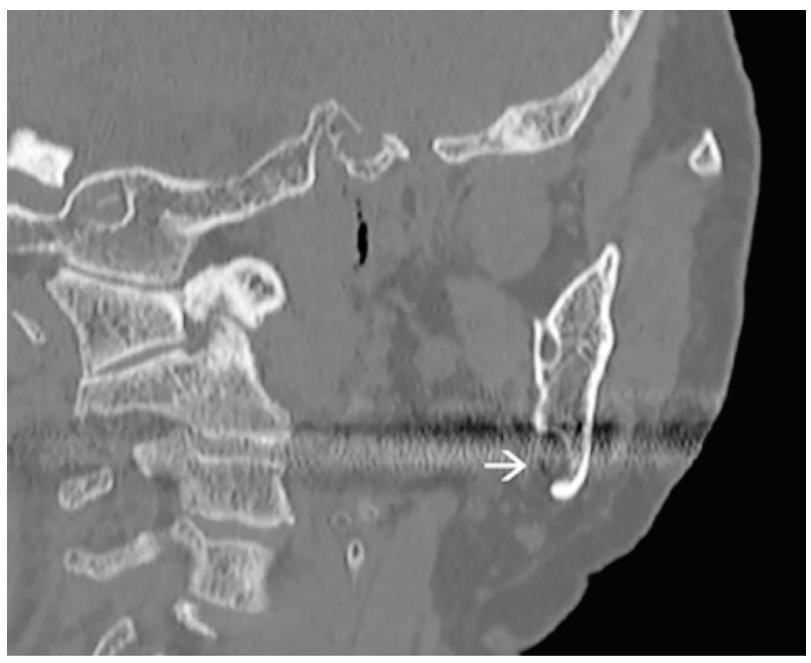

Figure 3 - Multislice computed tomography coronal slice demonstrates a hypodense area with lingual pit in mandible body. 


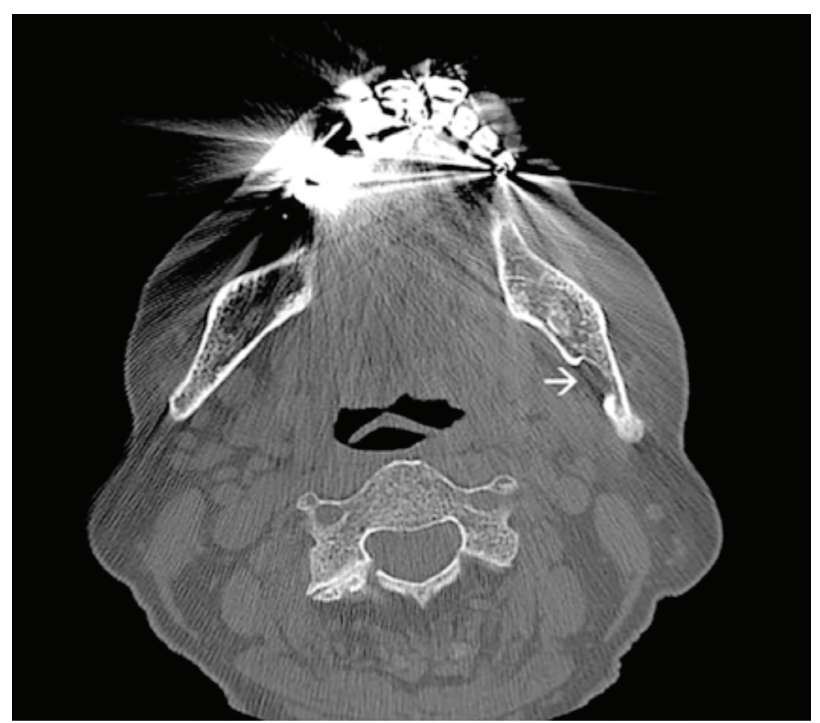

Figure 4 - Multislice computed tomography axial slice: hypodense area with lingual pit in mandible body, left area, near to mandible angle on left side.

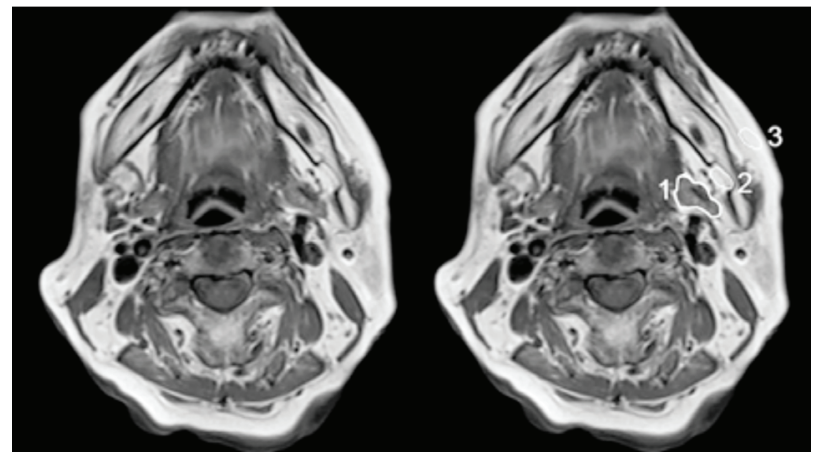

Figure 5 - T1-weighted axial slice image evinces hyperintense area in mandible body (2), left side, with a similar hyperintense signal to fat tissue (3). Note the submandibular gland area (1).

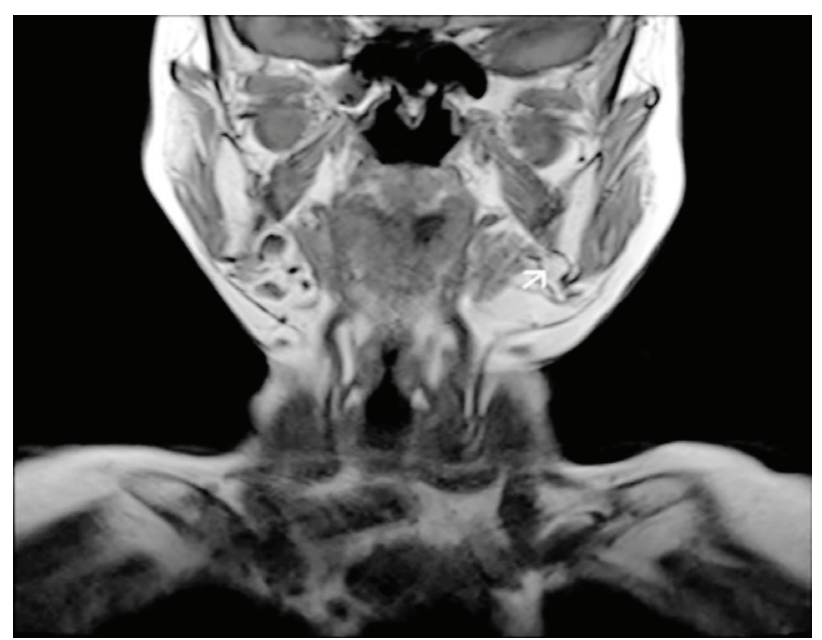

Figure 5 - T1-weighted coronal image evincing the hyperintense area in mandible body, left side.
Due to the imaging characteristics demonstrated by MCT complemented by MRI, it was concluded that the well-defined radiolucency noticed in panoramic radiograph was LMBD and other bone lesion varieties were then disregarded. Bone cavity was clearly fulfilled by soft tissue, notably continuous to the submandibular gland, and with a hyperintense signal similar to fat tissue.

After the final diagnosis of LMBD by MRI and MCT, patient and his dentist were oriented to regular follow ups.

\section{DISCUSSION}

In the present report, we describe a case of MBD found in a routine radiographic examination, in which the final diagnosis was defined as LMBD after MRI examination demonstrated the presence of soft tissue in the defect.

When LMBD was first described by Stafne, it was pointed that the defect was a well-defined radiolucent area, located on the posterior and medial surfaces of the mandible [7]. Indeed, on panoramic radiographs, MBDs typically exhibit a radiolucent area [4], with an oval or round shape (9) and well-defined limits [9], although ill-defined limits were also formerly depicted [2]. In the present report, these imaging features are present and depression limits are defined by a thin sclerotic discontinuous border. The LMBD is continuous to mandible base, as also demonstrated in a previous report [19], which mandible base similarly presents discontinuity of its cortical bone. However, in literature, we also found reports with thick LMBD margins, continuous to the mandible base, without any cortical interruption $[20,21]$. Furthermore, the present LMBD report shows a defect with a unilocular aspect, which is the most usual radiographic appearance in panoramic radiographs, although a multilocular defect has already been demonstrated [2].

Typically appearing LMBDs can be efficiently diagnosed with panoramic radiographs [4]. Nonetheless, the major disadvantage of panoramic radiographs is the technical limitation inherent to a two-dimensional examination: the lack of information about cortical mandible 
discontinuation in mandible base or even in mandible medial surfaces.

Computed tomography can demonstrate LMBD limits towards mandible margins and the defect peripheral origin, as well as the conservation of mandibular lingual cortical, which are fundamental to exclude hypotheses of other lesions that requires interventional treatment, such as traumatic osseous cyst $[20,22]$, other cystic aggressive bone lesions, or even malignant lesions [8,23]. In the present case reported, MCT was also convenient in establishing a negative relationship between the LMBD and the mandibular canal.

Notwithstanding, MCT is more appropriate to bone assessment than soft tissue evaluation and MBD requires characterization of the soft tissue internal content of the defect. Accordingly, MRI is advocate as the fundamental imaging examination for MBDs diagnosis [24-26]. The first description of MRI application in MBDs was in 1999 [26], and the main advantage of this imaging technique is the possibility of soft tissue evaluation in multiple echo sequences, without requiring contrast material administration [26] and not exposing the patient to ionizing radiation [2]. As demonstrated in this paper, MRI can show the LMBD soft tissues continuous to the submandibular gland [26] or the defect interior content, that appears hyperintense on both $\mathrm{T} 1$ and T2 weighted sequences [2]. Furthermore, sialography, not applied in this case, may also be an alternative in MBDs diagnosis [27], and it can confirm whether the glandular tissue is present in the defect [3].

Imaging diagnostic hypothesis in panoramic radiographs and MCT of MBDs should include benign and malignant jaw lesions [20], such as aneurysmal bone cyst [28], traumatic bone cyst, ameloblastoma [20], benign tumors of the salivary gland, lipoma, salivary gland hypertrophy [28], non-ossifying fibroma, brown tumor of hyperparathyroidism, osteoporotic bone marrow defect, giant cell tumor, multiple myeloma, eosinophilic granuloma, metastatic disease [1,3] and basal cell nevus syndrome [20].

\section{CONCLUSION}

In conclusion, imaging examinations can offer great details of MBDs, especially MRI, due to the fact that it can allows the professional to identify the glandular continuity to the defect or the defect soft tissue content. Furthermore, MSC can provide the possibility of mandibular cortical margins evaluation, which is convenient to MBDs diagnostic, particularly to LMBDs.

\section{REFERENCES}

1. Quesada-Gómez C, Valmaseda-CastellónE, Berini-Aytés L, Gay-Escoda C. Stafne bone cavity: a retrospective study of 11 cases. Med Oral Patol Oral Cir Bucal. 2006 May 1;11(3):E277-80.

2. Taysi M,Ozden C,Cankaya B, Olgac V, Yıldırım S. Stafne bone defect in the anterior mandible.Dentomaxillofac Radiol. 2014;43(7):20140075. doi:10.1259/ dmfr.20140075. Epub2014 Jun 24.

3. Etöz M, Etöz OA, Sahman H, Sekerci AE, Polat HB. An unusual case of multilocular Stafne bone cavity. Dentomaxillofac Radiol. 2012 Jan;41(1):75-8. doi: $10.1259 / \mathrm{dmfr} / 34731967$.

4. Kaya M,Ugur KS, Dagli E, Kurtaran H, Gunduz M. Stafne bone cavity containing ectopic parotid gland. Braz J Otorhinolaryngol. 2016 Apr 14. pii: S18088694(16)30023-4. doi: 101016/j.bjorl.2016.02.004.

5. Mauprivez C, Sahli Amor M, Khonsari RH. Magnetic resonance sialography of bilateral Stafne bone cavities. J Oral Maxillofac Surg. 2015 May;73(5):934.e1-7. doi:101016/j.joms.2015.01.034. Epub2015Feb 9.

6. Sisman Y, Miloglu 0, Sekerci AE, Yilmaz AB, Demirtas 0, Tokmak TT Radiographic evaluation on prevalence of Stafne bone defect: a study from two centres in Turkey. Dentomaxillofac Radiol. 2012 Feb;41(2):152-8. doi: 10.1259/dmfr/10586700. Epub2011Nov 10

7. Stafne E. Bone cavities situated near the angle of the mandible.J Am Dent Assoc. 194229(17);1969-72.

8. Shimizu M, Osa N, Okamura K, Yoshiura K.CT analysis of the Stafne's bone defects of the mandible. Dentomaxillofac Radiol. 2006 Mar;35(2):95-102.

9. Philipsen HP, Takata T, ReichartPA, Sato S, Suei Y. Lingual and buccal mandibular bone depressions: a review based on 583 cases from a worldwide literature survey, including 69 new cases from Japan. Dentomaxillofac Radiol. 2002 Sep;31(5):281-90.

10. Minowa K, Inoue N, Sawamura T, Matsuda A, Totsuka Y, Nakamura M Evaluation of static bone cavities with CT and MRI. Dentomaxillofac Radiol. 2003 Jan;32(1):2-7.

11. Campos PS, Panella J,Crusoé-Rebello IM, Azevedo RA, Pena N, Cunha T. Mandibular ramus-related Stafne's bone cavity. Dentomaxillofac Radiol. 2004 Jan;33(1):63-6.

12. Schneider T, Filo K, Stadlinger B, Locher M, Kruse AL, Lübbers HT. [An atypical Stafne cavity-multi-chamber bone lesion with bucal expansion. A case report] Swiss Dent J. 2014;124(5):545-55.

13. Assaf AT, Solaty M,Zrnc TA, Fuhrmann AW, Scheuer H, Heiland M, etal. Prevalence of Stafne's bone cavity--retrospective analysis of 14,005 panoramic views. In Vivo. 2014 Nov-Dec;28(6):1159-64. 
14. Krafft T,Eggert J,Karl M. A Stafne bone defect in the anterior mandible--a diagnostic dilemma. Quintessence Int. 2010 May;41(5):391-3.

15. Friedrich RE, Zustin J, Scheuer HA, Assaf AT, Gröbe A. An unilateral basal bone defect of the mandible occupied by fatty tissue: Stafne's cavity. In Vivo. 2012 Nov-Dec;26(6):1045-8.

16. Bornstein MM, WiestR, Balsiger R, ReichartPA. Anterior Stafne's bone cavity mimicking a periapical lesion of endodontic origin: report of two cases. J Endod. 2009 Nov;35(11):1598-602. doi: 10.1016/j.joen.2009.08.008. Epub2009 Sep 20.

17. Sisman Y, Etöz OA, Mavili E, Sahman H, Tarim Ertas E. Anterior Stafne bone defect mimicking a residual cyst: a case report. Dentomaxillofac Radiol. 2010 Feb;39(2):124-6. doi: 10.1259/dmfr/49320253.

18. Deyhimi P,Darisavi S, Khalesi S. Stafne bone cavity with ectopic salivary gland tissue in the anterior of mandible. Dent Res J (Isfahan). 2016 Sep;13(5):454-457.

19. Lee KH, Thiruchelvam JK, McDermottP.An Unusual Presentation of Stafne Bone Cyst. J Maxillofac Oral Surg. 2015 Sep;14(3):841-4. doi: 10.1007/s12663014-0737-2. Epub2015 Jan 13.

20. Münevveroğlu AP,Aydın KC. Stafne bone defect: report of two cases. Case Rep Dent. 2012;2012:654839. doi:101155/2012/654839. Epub2012 Sep 23.

21. Venkatesh E. Stafne bone cavity and cone-beam computed tomography: a report of two cases. J Korean Assoc Oral Maxillofac Surg. 2015 Jun;41(3):145-8. doi:10.5125/jkaoms.2015.41.3.145. Epub2015 Jun23.
22. Reuter I. An unusual case of Stafne bone cavity with extra-osseous course of the mandibular neurovascular bundle. Dentomaxillofac Radiol. 1998 May;27(3):189-91.

23. Saglam M, Salihoglu M, Sivrioglu AK, Kara K. Multimodality imaging of Stafne bone defect. BMJ Case Rep. 2013 Apr 19;2013. pii: bcr2013009483. doi: 10.1136/ bcr-2013-009483.

24. ProbstFA, Probst M, Maistreli IZ, Otto S, Troeltzsch M. Imaging characteristics of a Stafne bone cavity--panoramic radiography, computed tomography and magnetic resonance imaging. Oral Maxillofac Surg.2014 Sep;18(3):351-3. doi: 10.1007/s10006-014-0454-5. Epub2014 Aug 7.

25. Segev Y,Puterman M, Bodner L. Stafne bone cavity--magnetic resonance imaging. Med Oral Patol Oral Cir Bucal. 2006 Jul 1;11(4):E345-7.

26. Branstetter BF, Weissman JL, Kaplan SB. Imaging of a Stafne bone cavity: what MR adds and why a new name is needed. AJNR Am J Neuroradiol. 1999 Apr;20(4):587-9.

27. Lee Jl, Kang SJ, Jeon SP,Sun H. Stafne Bone Cavity of the Mandible. Arch Craniofac Surg. 2016 Sep;17(3):162-164. doi:10.7181/acfs.2016.17.3.162. Epub 2016 Sep 23

28. Chen CA, Ahn Y,Odell S, Mupparapu M, Graham DM. Developmental salivary gland depression in the ascending mandibular ramus: A cone-beam computed tomography study. Imaging Sci Dent. 2016 Sep;46(3):223-7. doi: 10.5624/isd.2016.46.3.223. Epub2016 Sep 20.

\section{Luciana Munhoz}

\section{(Corresponding address)}

Department of Stomatology, School of Dentistry, University of São Paulo

2227 Lineu Prestes Avenue.

Zip Code: 05508-000 São Paulo, SP, Brazil.

Telephone and fax number: +55 11 3091-7831.

Date submitted: 2018 Feb 20

E-mail address: dra.lucimunhoz@usp.br 